\title{
The Nature of Corporate Governance and Performance in the Conditions of Ownership Concentration
}

\author{
Article history: \\ Received: 10 June 2015 \\ Sent for revision: 15 July 2015 \\ Received in revised form: 22 October 2015 \\ Accepted:3 November 2015 \\ Available online: 1 April 2016
}

\begin{abstract}
The central research question and purpose of this topic is oriented on the analysis of concentration scope of share capital ownership in Serbia, and their relation to corporate performance. The article also attempts to give a suitable reply to the question as to what extent the concentration of share capital ownership has changed in comparison to previous, which was formed at the beginning of the process of transition and privatisation of the public property, which was used as the foundation for forming the corporate sector. The answers to these questions will be used to point to the nature of the corporate sector in Serbia, and the degree of development of the securities market. Research methodology involves the use parametric procedures due to the characteristics of the selected variables and the number of observations in the sample. Univariate ANOVA procedures and Pearson's correlation coefficient will be used.The corporate sector in Serbia achieves positive results but does not receive adequate market verification due to extreme ownership concentration and the dominant influence of the majority, or several large shareholders. Due to the privileged position of a small number of privileged shareholders, such a situation results in the expropriation of small shareholders, who remain helpless due to underdeveloped mechanisms of legal and institutional protection.
\end{abstract}

Keywords: Corporate Governance, Ownership Concentration, Performance, Transition

\footnotetext{
${ }^{1}$ University of Novi Sad, The Faculty of Economics Subotica,

${ }^{2}$ University of Novi Sad, The Faculty of Economics Subotica, marics@ef.uns.ac.rs 
Leković B., Marić S.: The Nature of Corporate Governance and Performance in the...

\section{Priroda korporativnog upravljanja i učinka u uslovima vlasničke koncentracije}

Apstrakt: Centralno istraživačko pitanje i svrha rada usmerena je na analizu obima koncentracije vlasništva akcionarskog kapitala u Republici Srbiji kao I međuzavisnost stepena koncentracija vlasništva akcionarskog kapitala $i$ korporativnih performansi. $U$ radu se nastoji dati odgovarajući odgovor na pitanje, koliko se postojeća koncentracija vlasništva kapitala promenila u odnosu na prethodni period, odnosno na stepen koncentracije koji je važio na početku procesa tranzicije i privatizacije društvene imovine a koji je poslužio kao osnov formiranja korporativnog sektora. Odgovori na ova pitanja poslužiće da ukažu na prirodu korporativnog sektora u Republici Srbiji, kao i stepen razvoja tržišta hartija od vrednosti. Metode istraživanja podrazumevaju upotrebu parametarskih procedura što nalaže karakteristike odabranih varijbli $i$ broj slučajeva u uzorku. U tom smislu koristiće se univarijantni ANOVA postupci i Pirsonov koeficijent korelacije.Opšti rezultati rada ukazuju da korporativni sektor u Republici Srbiji ostvaruje pozitivne rezultate ali koji nemaju adekvatnu tržišnu verifikaciju u prisustvu ekstremne vlasničke koncentracije i dominantnog uticaja većinskih ili malog broja velikih akcionara. Zahvaljujući privilegovanoj poziciji malog broja povlaštenih akcionara, koja se ostvaruje kao rezultat eksploatacije malih akcionara, pre svega usled nepostojanja ili nedovoljno razvijenog mehanizma pravne $i$ institucionalne zaštite.

Ključne reči: korporativno upravljanje, vlasnička koncentracija, učinak, trancizija

\section{Introduction}

The first association emerging in relation to corporations and corporate governance or management is separation of ownership from management. Insistence on distinguishing between and distancing these two categories point to their essential correlation, as ownership actually entails management, that is, right of ownership of shares (i.e. share capital) is directly proportional to rights to manage (i.e. participation in management of) corporation. It can be inferred from the above that the nature, in other words, the structure of ownership of a corporation determines the course of action, that is, priority in achieving business objectives, and, analogously, the priority of interests of the main stakeholders in a corporation's business, i.e. shareholders and managers, in addition to the corporation's performance. Thence the longstanding attempts to determine who actually controls modern corporations the shareholders or the managers (Berle and Means, 1932). The nature of 
Leković B., Marić S.: The Nature of Corporate Governance and Performance in the...

relationship between managers and shareholders results in discordant interests which often go as far as the ultimate absurd, i.e. conflicts. Such a situation is enabled by a range of relations in the ownership structure, which is manifested on the continuum line in the form of two extremes, i.e. corporations with an ultimate owner and publically listed, i.e. widely held. Small shareholders have a small percentage of participation in the share capital, not exceeding $10 \%$, and are therefore unable to make a significant impact on decision making. The ultimate owners hold a minimum of $20 \%$ shares, whereas other shareholders hold packages smaller than $20 \%$. In the first case, when there are ultimate, or even majority owners with the absolute decision making rights, ownership concentration results in the so-called principal-principal problem, implying that the major shareholders, owing to dominance over the corporation, abuse their position to achieve their own interests. Such a situation endangers the interests of small shareholders, who become indifferent regarding the issue of influencing the corporate management and decision making. In the second case, of widely held ownership, the corporation's management plays the dominant role, and the so-called principal-agent problem occurs, when a large number of small shareholders lacks adequate mechanisms of influencing and controlling the company management and the decision making process, which gives the professional management of the corporation to achieve their own and neglect the interests of small shareholders, which is earning return on share capital in the form of dividend. This ownership structure, that is, extent of ownership concentration, is related to corporate performance, as evidenced by the results of numerous academic (very often conflicting) studies in the areas of corporate management and governance.

The central research question and purpose of this topic is oriented on the analysis of concentration of share capital ownership in Serbia, and their relation to corporate performance. The article also attempts to give a suitable reply to the question as to what extent the concentration of share capital ownership has changed in comparison to previous, which was formed at the beginning of the process of transition and privatisation of the public property, which was used as the foundation for forming the corporate sector. The answers to these questions will be used to point to the nature of the corporate governance and corporate sector in Serbia, and the degree of development of the securities market. However, the situation has been strongly influenced by economic reforms on account of privatisation, liberalisation and globalisation in the past decades. One of the purposes of privatisation was to reform corporate governance and increase corporate efficiency (Prasnikar et al., 2014). 
Leković B., Marić S.: The Nature of Corporate Governance and Performance in the...

\section{Corporate governance, ownership concentration and corporate performance}

Success and speed of transition processes in different post-socialist countries, measured by the speed and the nature of privatization and corporate restructuring, the scope and extent of liberalization and degree of macroeconomic stabilization, produced rather diverse results regarding their institutional and economic systems (Milikić et al., 2012). The process of privatization is starting up transformation enterprises by new capital, new technology and new management knowledge, but a final result was poor performance (Nikolić and Kovačević, 2014). The level of intensity of changes in economic circumstances referred to as transition was sufficient to create a corporate sector which is significantly differentiated and specific by the nature of organisation, ownership structure and management model compared to earlier usual forms of corporation on the recognisable global markets. Although long-awaited, privatisation did not serve as a panacea for improving governance and management processes, and raising the efficiency of economy, as private ownership also manifested weaknesses, especially in the corporate sector. The previous privatisation, initiated in 1991, was annulled in 1994 as unfair, because it was carried out amid the conditions of privatisation (Labus, 2006). The privatisation process constituted the basis for the formation of corporate sector in Serbia, and the models of implementing this process are the root of the structure of ownership relations between shareholders. The second model of privatisation, implemented in 1997, was based on free distribution of shares, which introduced the principal-agent problem into the corporate sector, as it resulted in dispersion of ownership among a multitude of shareholders. Managers held dominant positions, whereas the large number of small shareholders had neither ways nor means to exert the required influence and control of business operation. The third privatisation model, launched in 2001 to resolve the aforementioned problem, entailed selling the $70 \%$ majority packages and thus resolving the problem of control over corporations by shareholder, but introduced a new principal-principal problem and raised the issue of protecting the small shareholders' interest. The emergence of the corporate sector resulted in high concentration of ownership in the hands of a small number of shareholders, while, on the other hand, a large number of small shareholder was left with negligible power of influencing corporate governance. But, despite learning of a traditional theory of industrial organization that the concentration has predominantly negative effect on firm debt (Miljković, Filipović and Tanasković, 2013). It was clearly pointed out how the institutional and historical framework of a country influence the development process of "good" corporate governance (Steger and Hartz, 2005). These circumstances create a dilemma as to how to regulate the behaviour or major shareholders in order to protect the interests 
Leković B., Marić S.: The Nature of Corporate Governance and Performance in the...

of the multitude of small shareholders without stepping back to the original problem (Becht, M. et al. 2005). Such a situation and property relations tend to make a significant impact on future investment in these corporations, which new investor avoid due to inadequate protection of ownership rights, so that thesecorporation find it hard to raise new finance and maintain low capitalisation rates (Labus, M. 2007). This paradoxical situation is even more difficult in transition countries due to weak legislative framework and inadequate development of institutions, which exposes and marginalises small shareholders' influence even more. All of this was identified in the EBRD's report on the state of the Serbian corporate sector entitled "Transition Report" (EBRD, 2006), where Serbia received a ranking of 2.3 (out of max. 4.3), and a particular concern is attracting small financial investors to invest into corporations.After a decade and a half, it could be concluded that what exists in Serbia is a corporate sector with widely held ownership resulting from high levels of legal protection of small shareholders, which was originally characteristic of the USA and Great Britain (Berle, A. A., and Gardiner, C. 1932, CIPE, 2002). Contrary to this, the countries of Europe and Asia are characterised by ownership concentration (S. Deakin, R.Hobbs. S. Konzclmann and F. Wilkinson, 2001). The true picture is obtained if the analysis of the distribution of the number of shareholders is done by the sizes of packages. Only then shall we have the realistic picture of the state of the corporate sector in Serbia in terms of ownership concentration, indicating that $67.84 \%$ of large and majority share packages, and also dominant participation of legal entities in the ownership structure.

All of the above is also obvious from the data in Table 1, where the AngloAmerican and Euro-Asian markets have come close to one another to a significant extent regarding the mean value of the ownership share of the largest shareholder, unlike Serbia, where it is twice as much. The conclusion about the current situation in the corporate sector could be that high ownership concentration and inadequate legislative protection of minority shareholders, which makes a negative impact not only in the form of expropriation of small shareholders by the controlling one, but also transfer of shares from the employees (the small shareholders) to the majority shareholders, lack of trust among investors, low capitalization rates and attempts at transforming joint-stock companies into limited liability companies, which can all result not only in weakening or stagnation in development, but also disappearance of joint-stock companies and the stock exchange, that is, the entire corporate sector (Centre for Liberal-Democratic Studies, 2008). The countries of Ex-Yugoslavia with still relatively high employee influence (and ownership) are to be considered exceptions with an insecure future anyway (Dobák and Steger, 2003). 
Leković B., Marić S.: The Nature of Corporate Governance and Performance in the...

Table 1. The largest shareholders' ownership participation

\begin{tabular}{|c|c|c|c|}
\hline & $\begin{array}{l}\text { Anglo - American* } \\
\text { market }(\%), 2009\end{array}$ & $\begin{array}{c}\text { Euro - Asian }{ }^{*} \\
\text { market }(\%), 2009 \text {, }\end{array}$ & $\begin{array}{c}\text { Serbian** } \\
\text { market }(\%), 2011\end{array}$ \\
\hline Average ownership & 26.61 & 33.95 & 68.74 \\
\hline Minimum ownership & 4.75 & 1.96 & 21.79 \\
\hline Maximum ownership & 68.10 & 90.18 & 100.00 \\
\hline
\end{tabular}

Source: * Earle, John S., Csaba Kucsera, and Álmos Telegdy. 2005., ** the author's calculation

The current structure of corporate ownership, determining the problems of corporate governance and management to a great extent, is predominantly caused by the chosen privatisation models and the original limiting factor that made an impact on the corporate sector and greatly hindered its development due to discouraging new investors. Thus, the securities market (notably the Stock Exchange) predominantly becomes a mechanism for redistribution of ownership rights, and negligible as a financing mechanism of this sector.

Viewed from the aspect of corporation, ownership concentration can improve performance (Shleifer and Vishny, 1986), which also entails expropriation of small by majority shareholders in order to achieve personal gains (Holderness and Sheehan, 1988, Barclay and Holderness, 1989, Shleifer and Vishny, 1997), which, in any case, results in discouraging new investors and problems in finding additional finance through new share issues. Thus endangered liquidity may reflect to the market value of shares as a measure of the corporate management's performance (Holmstrom and Tirole, 1993). However, in the multitude of studies on the topic of correlation between corporate performance and ownership concentration, we find contradicting results, such as the works of Demsetz and Lehn (1985), which do not confirm the correlation between the concentration level and profit, then McConnell and Servaes (1990), who do not highlight the correlation between the market value ratio and property costs. A general viewpoint regarding the above may be expressed as follows: there is currently no generally established positive or negative impact of the ownership package on the value of a corporation, as the existing available data are insufficient for definite decision (Holdernes, 2003).

As well as the mentioned existing contrasting results of research into this topic, the above conclusion provides a rationale for all and any attempts at finding an appropriate answer and intention of this article. The relevance of this study gains significance in Serbia due to the current phase in its economic development and the nature of the corporate sector. The next essential factor for the potential results of this research, and the possible message of the study, is the manner of expressing the observed phenomena, that is, the type of measures to be used pertaining to the relations and 
Leković B., Marić S.: The Nature of Corporate Governance and Performance in the...

correlations between ownership concentration and corporate performance. Out of the available expert and academic literature and scientific studies conducting so far, the markedly dominant approach of Demsetz and Lehn (1985) uses shareholder groups, as the total ownership participation of 5 or 20 largest shareholders, as the rate of ownership concentration. The efforts to express ownership concentration may include distinction of majority shareholders (Holderness and Sheehan, 1988), then 5 largest ones (Prowse, 1992, Hovey, Li and Naughton, 2003), or singling out the largest shareholder. (Claessens et al., 2002). However, in situations when there is a dominant majority shareholder, then the measurement of their impact on corporate performance is much more relevant than that of a group of 5 largest shareholders, or another group (Earle et al., 2005). Otherwise, measuring the impact of a group makes sense only if there are several large shareholders who can achieve control of the corporation as a group.

\section{Data and methodology}

\subsection{The sample and the data}

The sample of this study includes corporations (incorporated companies, jointstock companies) classified as large corporations by the Serbian Business Registers Agency in compliance with the Law on Accounting and Auditing (Issues 46/06 and 111/09 of the Official Gazette of the Republic of Serbia. The next essential criterion that reduced the number of corporations in the sample from 318 to 228 is listing on the Belgrade Stock Exchange, to enable availability of data on performance and structure of ownership, and exclusion of financial sector corporations from the following analysis due to speculative capital. Analysing the data of a sample of this size requires the application of parametric mathematic and statistical procedures, and thus provides more reliable and accurate analysis of research data.

\subsection{Corporate performance as the dependent variable}

In view of all the shortcomings of the ratio indicators, it is impossible to compare corporate subject without using these figures. Performance as the dependent variable will be represented by variables for measuring corporate performance with a determined package of official indicators (The indicators have been calculated based on the last annual financial reports (for year 2011), submitted by corporations to the Belgrade Stock Exchange.) representing an integral part of the Belgrade Stock Exchange's reports for corporations whose shares are quoted on the Stock Exchange. These 
Leković B., Marić S.: The Nature of Corporate Governance and Performance in the...

indicators are intended for shareholders and possible investors, providing information on the advantages of investing in particular corporation. This package includes the P/E ratio, the P/B ratio, indicating the corporations' market value, and EPS analysis and ROE as profitability indicators (The indicators have been calculated based on the last annual financial reports (for year 2011), submitted by corporations to the Belgrade Stock Exchange.)

Table 2. Descriptive statistics for performance indicators

\begin{tabular}{|c|c|c|c|c|c|c|c|c|c|}
\hline & \multirow{2}{*}{$\begin{array}{c}\mathrm{N} \\
\text { Stat. }\end{array}$} & \multirow{2}{*}{$\begin{array}{l}\text { Minimum } \\
\text { Stat. }\end{array}$} & \multirow{2}{*}{$\begin{array}{l}\text { Maximum } \\
\text { Stat. }\end{array}$} & \multirow{2}{*}{$\begin{array}{l}\text { Mean } \\
\text { Stat. }\end{array}$} & \multirow{2}{*}{$\begin{array}{l}\text { Std. Deviation } \\
\text { Stat. }\end{array}$} & \multicolumn{2}{|c|}{ Skewness } & \multicolumn{2}{|c|}{ Kurtosis } \\
\hline & & & & & & Stat. & $\begin{array}{c}\text { Std. } \\
\text { Erro } \\
r\end{array}$ & Stat. & $\begin{array}{l}\text { Std. } \\
\text { Error }\end{array}$ \\
\hline $\begin{array}{l}\text { EPS } \\
P / E \\
P / B\end{array}$ & $\begin{array}{r}87 \\
87 \\
143\end{array}$ & $\begin{array}{r}, 00000 \\
, 12000 \\
-342,92\end{array}$ & $\begin{array}{r}38983,90 \\
2541,25 \\
337,51\end{array}$ & $\begin{array}{r}1409,033 \\
121,395 \\
, 195\end{array}$ & $\begin{array}{r}4756,55 \\
376,47 \\
41,25\end{array}$ & $\begin{array}{l}6,433 \\
4,605 \\
-, 296\end{array}$ & $\begin{array}{l}258 \\
, 258 \\
203\end{array}$ & $\begin{array}{l}47,286 \\
23,375 \\
65,135\end{array}$ & $\begin{array}{l}, 511 \\
, 511 \\
, 403\end{array}$ \\
\hline ROE & 141 & $-1032,31$ & 3571,77 & 12,604 & 318,45 & 9,821 & ,204 & $\begin{array}{r}114,18 \\
5\end{array}$ & ,406 \\
\hline $\begin{array}{l}\text { Valid N } \\
\text { (listwise) }\end{array}$ & 87 & & & & & & & & \\
\hline
\end{tabular}

Source:The author's calculations

The P/E (price-to-earnings) ratio is the proportion of the current share price on the stock market and earnings per share. The value of the P/E indicator is the amount that a potential investor (or shareholder) should pay when buying a share in order to secure future annual earnings of 1 dinar per share. A highly complex indicator expressing the market assessment of a corporation's growth and development, determining a whole range of factor such as the interest rate market trend, expected share growth and risk aversion level. High level of this indicators shows that the prospects of future growth are high and the climate for investors is favourable. Financial analysts opine that P/E of well managed and stable corporations usually ranges between 15 and 30 . According to the data of Standard \& Poor's 15 (See www.standardandpoors.com), the S\&P 500 stock market index for the period of 20 years (1982-2000) had P/E ratio value ranging from 8 to 28 . The $P / B$ (price-to-book) ratio is the proportion of a share's market price and its book value. If the value of this indicator is higher than 1 , it means that the corporation's performance is high, and so is the investors' and shareholders' trust in the corporation's financial reports. EPS (earnings per share) analysis means calculating profit per share. It is an integral part of the P/E ratio and should be used in combination with other indicators due to its numerous shortcomings. Shareholders see the main reason for investment and reward for the risk taken in ROE (return on equity). This is a major performance indicator in the case of corporations. As return on share capital, it represents the proportion of net profit share capital's book value. A highly important 
Leković B., Marić S.: The Nature of Corporate Governance and Performance in the...

indicator in corporate operation, it essentially shows how successfully a corporation's management uses the share capital.

Table 2 shows the descriptive parameters of all the corporations in the samples for dependent variables (performance indicators), where we can see the ranges from minimum to maximum values as well as the mean value. Based on the high positive values of skewness and kurtosis for all performance indicators, it can be concluded that the distribution of values of he analysed values for the selected cases in the sample deviates from the normal distribution, which is characteristic of social phenomena anyway, and an assumption that can be neglected in these circumstances when the samples are large and parametric procedures are applied in data analysis.

\subsection{Ownership concentration}

Data availability provides a basis for analysing data on ownership structure in terms of number of shareholders and the percentage of participation in the total share capital. The official source of information on the ownership structure of the selected corporation in the sample is the Central Securities Depository and Clearing House (See http://www.crhov.rs/ accessed December 2013) at the corporation level.

Table 3. Descriptive statistics of concentration measures

\begin{tabular}{|c|c|c|c|c|c|c|c|c|c|}
\hline & \multirow{2}{*}{$\begin{array}{c}\mathrm{N} \\
\text { Stat }\end{array}$} & \multirow{2}{*}{$\begin{array}{l}\text { Min } \\
\text { Stat }\end{array}$} & \multirow{2}{*}{$\begin{array}{l}\text { Max } \\
\text { Stat }\end{array}$} & \multirow{2}{*}{$\begin{array}{l}\text { Mean } \\
\text { Stat }\end{array}$} & \multirow{2}{*}{$\begin{array}{l}\text { Std. Dev. } \\
\text { Stat }\end{array}$} & \multicolumn{2}{|c|}{ Skewness } & \multicolumn{2}{|c|}{ Kurtosis } \\
\hline & & & & & & Stat & $\begin{array}{l}\text { Std. } \\
\text { Err. }\end{array}$ & Stat & Std. Err. \\
\hline Top_1 & 223 &, 00 & 100,00 & 62,5008 & 31,7110 &,- 626 &, 163 &,- 771 & ,324 \\
\hline Top_2 & 223 & , 00000 & 100,00 & 70,8049 & 31,0243 & $-1,093$ & , 163 & ,127 & 324 \\
\hline Top_3 & 223 & ,00000 & 100,00 & 74,0893 & 30,4576 & $-1,351$ & ,163 & ,783 & ,324 \\
\hline Top_5 & 223 & ,00000 & 100,00 & 76,7159 & 29,9994 & $-1,578$ & ,163 & $\begin{array}{r}1,43 \\
0\end{array}$ & ,324 \\
\hline $\begin{array}{l}\text { Valid N } \\
\text { (listwise) }\end{array}$ & 223 & & & & & & & & \\
\hline
\end{tabular}

Source: Author's calculation

As regards the ownership structure of corporations, that is, the degree of ownership concentration, it refers to the way portfolio (the total share issue) of voting stock is distributed among shareholders, and especially which measures should be used to express the degree of ownership concentration in order to establish certain rules and correlations to corporate performance. Concentration of ownership can range from widely held, when the majority package of shares is in the hands of a large number of small shareholders, to closely held, when the controlling package is in the hands of a small number of large shareholders. Based on the above, it can be noted that some of the measures most used for expressing the rate of ownership concentration is A5, as the percentage of participation of the first 5 shareholders in the total share 
Leković B., Marić S.: The Nature of Corporate Governance and Performance in the...

issue, then $\mathrm{A} 20$, as the percentage of participation of the first 20 shareholders in the total share issue, and $\mathrm{AH}$, as the Herfindahl index of ownership concentration, which was calculated as the sum of squares of the percentage of shares owned by each shareholder (Demsetz, H. and, Lehn, K., 1985). Such an approach is acceptable for countries with a once high percentage of widely held corporations such as the English-speaking countries, but the current circumstances have resulted in a considerable shift towards closely held ownership, as seen in Table 1. A significantly high degree of closely held share ownership is present in countries with underdeveloped corporate sector and capital market, which is especially characteristic of transition countries. Due to extreme ownership concentration in the Serbian corporate sector, or more precisely, due to dominance of majority shareholders in most cases of observed corporations, we are forced to consider the impact of the largest shareholder (Earle at al., 2005), choose and adapt the measures of expressing ownership concentration in corporation which will produce certain results related to the study of correlation with corporate performance. In this study, we have opted for measures Top_1, as the percentage of participation of the largest shareholder, Top_2, as the percentage of participation of two largest shareholders, Top_3, as the percentage of participation of three largest shareholders, and Top_5, as the percentage of participation of five largest shareholders. This approach is also corroborated by very high mean values of the selected measures, which is obvious in Table, where the mean value of Top_1 amounts to $62.5008 \%$, Top_2 amounts to $70.8049 \%$, Top_3 amounts to 74.0893 , and Top_5 is at the level of $76.7159 \%$. Skewness and kurtosis indicators for the degrees of ownership concentration in the form of high negative values point to deviation of data distribution of these rates from the normal distribution, but due to the above mentioned conditions, the application of parametric techniques in the future analyses is justified.

Table 4. Descriptive statistics of degrees of ownership concentrationG1, G2, G3

\begin{tabular}{llrrrr}
\hline & & $\begin{array}{c}\text { Frequenc } \\
\text { y }\end{array}$ & Percent & Valid Percent & Cumulative Percent \\
\hline \multirow{4}{*}{ Valid } & Small Shareholders & 8 & 3,6 & 3,9 & 3,9 \\
& Large Shareholders & 39 & 17,5 & 19,0 & 22,9 \\
& Majority Shareholders & 158 & 70,9 & 77,1 & 100,0 \\
& Total & 205 & 91,9 & 100,0 & \\
Missing & System & 18 & 8,1 & & \\
\hline
\end{tabular}

Source: Author's calculation

The next selected method of expressing ownership structure in terms of concentration rate aimed at studying difference in performance is dividing corporation into three groups, represented as measures G1, G2, and G3. 
Leković B., Marić S.: The Nature of Corporate Governance and Performance in the...

Group G1 includes corporations with small shareholders or widely held corporations, with participation rate not higher than $20 \%$ voting shares; $\mathrm{G} 2$ are closely held corporations, where a single shareholder owns minimum $20 \%$ shares, known as corporations with an ultimate owner, and G3 will represent corporations with a majority shareholder, where a single shareholder owns the controlling package higher than 50\% (Florencio López de Silanes, Rafael La Porta, and Andrei Shleifer; 1999).

Table 4 demonstrates that, according to the frequency of corporations in the sample, corporations with a majority shareholder (G3) account for $77.1 \%$, corporations with an ultimate owner (G2\%) comprise $19.0 \%$, whereas the proportion of corporations owned by small shareholders, where the ownership of the largest shareholder does not exceed $20 \%$, i.e. group G1, amounts to $3.9 \%$. In addition to highlighting the high ownership concentration of the corporations in the sample, it also indicates the negligible influence of the variable in the following analysis.

\subsection{Hypotheses and methodology}

The basic research assumption of this study is based on all the above presented facts and opinions describing the state of the Serbian corporate sector. First and foremost, it refers to the ownership structure of corporations, which was retained from the time of formation of the corporate sector, extreme ownership concentration, participation of majority shareholders in governance and management, low professionalisation level of the management team, low capitalisation rate of corporation, negligible protection and influence of small shareholders, and a whole range of other circumstances depicting the state of the corporate sector.

H1: There is a positive correlation between ownership concentration and corporate performance.

Hypothesis $\mathrm{H} 1$ will be tested with Pearson's rho correlation coefficient to determine the direction and strength of the connection between the groups of variables of ownership concentration and corporate performance.

The following hypothesis is due to the nature of the available data and the characteristics of the sample, but also the assumption that equally strong impact on the company's management can be exerted both by a single majority owner and by a group of (several) large shareholders.

H1a: there is no statistically significant difference between the group of corporations with a majority shareholder (G3) and the group of corporation with large shareholders (G2) in terms of corporate performance. 
Leković B., Marić S.: The Nature of Corporate Governance and Performance in the...

Hypothesis $\mathrm{H} 1 \mathrm{a}$ will be tested with ANOVA analysis of variance as a parametric technique suitable for comparing two groups at the level of sample size with more than 30 observations, that is, large samples meeting the prerequisites of normal distribution.

\section{Analyses of results and discussion}

The link between ownership concentration expressed using variables Top_1, percentage of the largest shareholder Top_2, percentage share of the two largest shareholders, Top_3, percentage of the evening three shareholders, Top_5, percentage of top five shareholders with performance indicators, EPS, $\mathrm{P} / \mathrm{E}, \mathrm{P} / \mathrm{B}$ and ROE and hypothesis $\mathrm{H} 1$ was tested by using the Pearson's coefficient whose results are represented in table 5.

Table 5. Relationship between the ownership concentration rate and corporate performance

\begin{tabular}{|c|c|c|c|c|c|}
\hline & & EPS & P/E & $P / B$ & ROE \\
\hline \multirow[t]{3}{*}{ Top_1 } & Pearson Correlation &, 062 &,- 179 &, 073 &, 140 \\
\hline & Sig. (2-tailed) &, 569 &, 097 & ,389 & ,097 \\
\hline & $\mathrm{N}$ & 87 & 87 & 143 & 141 \\
\hline \multirow[t]{3}{*}{ Top_2 } & Pearson Correlation & 045 &,- 195 & ,062 & ,113 \\
\hline & Sig. (2-tailed) & 677 &, 070 & ,463 & , 183 \\
\hline & $\mathrm{N}$ & 87 & 87 & 143 & 141 \\
\hline \multirow[t]{3}{*}{ Top_3 } & Pearson Correlation & ,046 &,- 202 & ,057 & ,097 \\
\hline & Sig. (2-tailed) & 670 &, 061 & ,496 & ,254 \\
\hline & $\mathrm{N}$ & 87 & 87 & 143 & 141 \\
\hline \multirow[t]{3}{*}{ Top_5 } & Pearson Correlation & ,055 &,$- 211^{*}$ & ,047 & ,076 \\
\hline & Sig. (2-tailed) & 614 &, 049 & ,578 & ,368 \\
\hline & $\mathrm{N}$ & 87 & 87 & 143 & 141 \\
\hline
\end{tabular}

Source: Author's calculation

Analysis of results shows both positive and negative relations of the correlation of the variables of ownership concentration and corporate performance. Also, to make the analysis complete, it is also necessary to combine profitability (ROE and EPS) and market value (P/E and $P / B$ ) indicators, due to the specific circumstances of the corporate sector, transition milieu, and low market verification of corporate performance, and also due to differences in the ways of observing and expressing business performance, which is all manifested through extreme ownership concentration, and limited ability of obtaining additional finance. Profitability indicators in the conditions of high ownership concentration and reluctance of possible future investors may prove to be more reliable performance indicators. There is a positive 
Leković B., Marić S.: The Nature of Corporate Governance and Performance in the...

correlation between the ownership indicators and profitability indicators (EPS and ROE) at the level of statistical significance in the case of the Top_5 ownership concentration rate. What is also obvious is the stronger positive correlation between profitability indicators and a higher degree of ownership concentration. This situation can be interpreted by the ability of a smaller number of large shareholders to exert control over the corporation's governance and management, which reflects directly on the performance. The indicators of ownership concentration rate by corporate performance market value indicators $P / E(P / B)$ show contradicting relations, but also a strong connection to the advantage of the Top_1 rate, i.e. the majority shareholder, which has the lowest negative correlation with $\mathrm{P} / \mathrm{E}$ and the highest positive correlation with $(\mathrm{P} / \mathrm{B})$ at the level of medium strong connection. Negative correlation between ownership concentration and the P/E indicator is to be expected, and is explained by a faster growth in earning per share than share market price. Negative and low positive correlation between ownership concentration and market indicators of corporate performance is the consequence of low confidence of the market and inadequate level of minority shareholders in corporations with large or majority shareholders. Positive correlation is achieved in the case of performance indicators EPS, P/B and ROE, while remaining at the medium strength level only for EPS and ROE indicators. Negative correlation between the ownership concentration rate and the P/E performance indicator is to be expected, as the EPS profitability indicator is in reverse proportion to the above mentioned, and reflects the market value of the future earnings at 1 dinar per share.

Table 6. ANOVA - comparison between groups of corporation with majority and large owners in terms of performance

\begin{tabular}{|c|c|c|c|c|c|c|}
\hline & & Sum of Squares & $\mathrm{df}$ & Mean Square & $\mathrm{F}$ & Sig. \\
\hline \multirow[t]{3}{*}{ EPS } & $\begin{array}{l}\text { Between } \\
\text { Groups }\end{array}$ & 8018104,870 & 2 & 4009052,435 & ,158 & ,854 \\
\hline & Within Groups & 1924054285,314 & 76 & 25316503,754 & & \\
\hline & Total & 1932072390,184 & 78 & & & \\
\hline \multirow[t]{3}{*}{ P/E } & $\begin{array}{l}\text { Between } \\
\text { Groups }\end{array}$ & 10450527965,968 & 2 & 5225263982,984 & 12,372 &, 000 \\
\hline & Within Groups & 32098779837,459 & 76 & 422352366,282 & & \\
\hline & Total & 42549307803,428 & 78 & & & \\
\hline \multirow[t]{3}{*}{$P / B$} & $\begin{array}{l}\text { Between } \\
\text { Groups }\end{array}$ & 1,647 & 2 & ,823 & ,000 & 1,000 \\
\hline & Within Groups & 241612,600 & 129 & 1872,966 & & \\
\hline & Total & 241614,246 & 131 & & & \\
\hline \multirow[t]{3}{*}{ ROE } & $\begin{array}{l}\text { Between } \\
\text { Groups }\end{array}$ & 291802,499 & 2 & 145901,249 & 1,333 & ,267 \\
\hline & Within Groups & 13903034,659 & 127 & 109472,714 & & \\
\hline & Total & 14194837,158 & 129 & & & \\
\hline
\end{tabular}

Source: Author's calculation 
Leković B., Marić S.: The Nature of Corporate Governance and Performance in the...

Testing the hypothesis $\mathrm{H} 1 \mathrm{a}$ reinforces the previous analysis in terms of verifying the statistical significance of the difference of independent variables Top_1, Top_2, Top_3 and Top_5, or, more precisely, comparison between the groups of corporations of small (G1), large (G2) and majority (G3) shareholders.

ANOVA analysis of comparison between groups G1, G2 and G3 identified a statistically significant difference $(p=.000)$ only by criterion $P / E$, which features as he most indicative indicator of the market-based verification of performance depending on the ownership concentration rate measured by variable $\mathrm{G}$. This can be explained by the fact that large shareholders, who own more than $20 \%$ of the total share issue, can exert an approximately similar level of control over and influence on corporate management teams like the majority shareholders with $50 \%$ plus one vote, without major difference in achieved performance, whereas the performance level is slightly higher in the G3 group of corporations with majority owners.

Table 7. Multiple comparisons

\begin{tabular}{|c|c|c|c|c|c|c|c|}
\hline \multirow[b]{2}{*}{$\begin{array}{l}\text { Dependen } \\
\text { t Variable }\end{array}$} & \multirow{2}{*}{$\begin{array}{c}(\mathrm{l}) \\
\text { Ownership } \\
\text { concentration }\end{array}$} & \multirow{2}{*}{$\begin{array}{c}(\mathrm{J}) \\
\text { Ownership } \\
\text { concentration }\end{array}$} & \multirow{2}{*}{$\begin{array}{c}\text { Mean } \\
\text { Difference } \\
(I-J)\end{array}$} & \multirow[b]{2}{*}{ Std. Error } & \multirow[b]{2}{*}{ Sig. } & \multicolumn{2}{|c|}{ 95\% Confidence Interval } \\
\hline & & & & & & $\begin{array}{l}\text { Lower } \\
\text { Bound }\end{array}$ & Upper Bound \\
\hline \multirow[t]{5}{*}{ EPS } & G1 & $\begin{array}{l}\mathrm{G} 2 \\
\mathrm{G} 3\end{array}$ & $\begin{array}{r}1605,36 \\
1251,72 \\
\end{array}$ & $\begin{array}{l}2852,62 \\
2596,95\end{array}$ & $\begin{array}{l}, 840 \\
, 880 \\
\end{array}$ & $\begin{array}{l}-5213,76 \\
-4956,22\end{array}$ & $\begin{array}{l}8424,50 \\
7459,68 \\
\end{array}$ \\
\hline & G2 & G1 & $-1605,36$ & 2852,62 & 840 & $-8424,50$ & 5213,76 \\
\hline & & G3 & $-353,63$ & 1491,08 & ,969 & $-3918,05$ & 3210,77 \\
\hline & G3 & G1 & $-1251,72$ & 2596,95 & 880 & $-7459,68$ & 4956,22 \\
\hline & & G2 & 353,63 & 1491,08 & ,969 & $-3210,77$ & 3918,05 \\
\hline \multirow[t]{6}{*}{$\mathrm{P} / \mathrm{E}$} & $\mathrm{G} 1$ & G2 & $52424,49^{*}$ & 11651,44 &, 000 & 24571,95 & 80277,02 \\
\hline & & G3 & $52467,15^{*}$ & 10607,16 &, 000 & 27110,95 & 77823,36 \\
\hline & G2 & $\mathrm{G} 1$ & $-52424,49^{*}$ & 11651,44 &, 000 & $-80277,02$ & $-24571,95$ \\
\hline & & G3 & 42,66 & 6090,30 & 1,000 & $-14516,08$ & 14601,42 \\
\hline & G3 & G1 & $-52467,15^{*}$ & 10607,16 & 000 & $-77823,36$ & $-27110,95$ \\
\hline & & G2 & $-42,66$ & 6090,30 & 1,000 & $-14601,42$ & 14516,08 \\
\hline \multirow[t]{6}{*}{$P / B$} & G1 & G3 & 36503 & 21,07 & 1,000 & $-49,59$ & 50,32 \\
\hline & & G3 &, 51950 & 19,83 & 1,000 & $-46,50$ & 47,54 \\
\hline & G2 & G1 &,- 36503 & 21,07 & 1,000 & $-50,32$ & 49,59 \\
\hline & & G2 & 15446 & 9,38 & 1,000 & $-22,10$ & 22,40 \\
\hline & G3 & G1 &,- 51950 & 19,83 & 1,000 & $-47,54$ & 46,50 \\
\hline & & G2 &,- 15446 & 9,38 & 1,000 & $-22,40$ & 22,10 \\
\hline \multirow[t]{6}{*}{ ROE } & G1 & G2 & $-172,54$ & 161,57 &, 536 & $-555,70$ & 210,62 \\
\hline & & G3 & $-228,80$ & 151,65 & ,290 & $-588,46$ & 130,85 \\
\hline & G2 & $\mathrm{G} 1$ & 172,54 & 161,57 &, 536 & $-210,62$ & 555,70 \\
\hline & & G3 & $-56,26$ & 72,91 &, 721 & $-229,18$ & 116,64 \\
\hline & G3 & $\mathrm{G} 1$ & 228,80 & 151,65 & ,290 & $-130,85$ & 588,46 \\
\hline & & G2 & 56,26 & 72,91 & ,721 & $-116,64$ & 229,18 \\
\hline
\end{tabular}

Source: Author's calculation 
Leković B., Marić S.: The Nature of Corporate Governance and Performance in the...

Subsequent analysis of the multiple comparisons of the observed properties between the defined groups $(G)$ of corporations with different ownership concentration rates points to the existence of a statistically significant difference, when mutually compared, between all three groups in terms of isolated feature of performance $\mathrm{P} / \mathrm{E}$, except the mutual correlation between $\mathrm{G} 2$ and $\mathrm{G} 3$, in compliance with previous interpretation.

\section{Conclusion}

The corporate sector in Serbia achieves positive results which does not receive adequate market verification due to extreme ownership concentration and the dominant influence of the majority, or several large shareholders. Due to the privileged position of a small number of privileged shareholders, such a situation results in the expropriation of small shareholders, who remain helpless due to underdeveloped mechanisms of legal and institutional protection. Because of the manifest principal - principal problem, corporations have very low capitalisation levels and major limitations in additional financing, i.e. issuing new shares, which is reflected in low confidence of the market and low prices of these corporations' shares. This is all a consequence of the transition model, underdeveloped securities market and the infancy stage of the Belgrade Stock Exchange.

The common denominator of all the attempts at privatisation and transition to market economy and earning model on these foundations in our country is the deep impact of current authorities on the legislative and practical solutions over a period of more than two decades. This corporate governance process is therefore approximately as unsuccessful at the beginning as today. Domination of authoritarian models did not even offer the possibility for a different outcome of this crucially important transition project, whose consequences include criminalisation of society, delayed development, formation of the "elite of the resourceful", who "legally" acquired "their own ownership empires" in the periods of political eligibility. The various forms of domination in ownership enabled, as it still does, intertwining these measures instead of separating the ownership and managing sphere, to such an extent that the question arises as to what is the purpose of top managers.

\section{References}

Becht, M., Bolton, P. and A. Röell (2005), Corporate Governance and Control, ECGI Working Paper Series in Finance, European Corporate Governance Institute;

Berle, A. A., \& Gardiner, C. (1932), Means. The Modern Corporation and Private Property, 45; 
Leković B., Marić S.: The Nature of Corporate Governance and Performance in the...

Centar zaliberalno-demokratskestudije (2008), Korporativnoupravljanje: pet godinakasnije - stanje u Srbiji;

CIPE (Center for International Private Enterprise) (2002), Instituting Corporate Governance in Developing, Emerging and Transitional Economies, A Handbook;

Claessens, Stijn, Simeon Djankov, Joseph P.H. Fan, and Larry H.P. Lang (2002), "Disentangling the Incentive and Entrenchment Effects of Large Shareholdings." Journal of Finance, 57(6), 2741-2771;

Clay, Michael J., and Clifford G. Holderness (1989): "Private Benefits from Control of Public Corporations." Journal of Financial Economics, 25(2), 371-395;

Demsetz, H. and Lehn, K., 1985: The structure of corporate ownership: causes and consequences. The Journal of Political Economy 93(6), 1155-1177;

Dobák, M., \& Steger, T. (2003). Corporate Governance in Central and Eastern Europe-An introductory review. Journal for East European Management Studies, 223-235.

Earle, John S., CsabaKucsera, and ÁlmosTelegdy. (2005). "Ownership Concentration and Corporate Performance on the Budapest Stock Exchange: Do Too Many Cooks Spoil the Goulash?" Corporate Governance: An International Review 13(2) (March): 254-264;

Florencio López de Silanes, Rafael La Porta, and Andrei Shleifer (1999), "Corporate Ownership Around the World" Journal of Finance 54(2) 471-517

Holderness, Clifford G. (2003), "A Survey of Blockholders and Corporate Control." FRBNY Economic Policy Review, 9(1), 51-64;

Holderness, Clifford G., and Dennis P. Sheehan (1988), "The Role of Majority Shareholders in Publicly Held Corporations: An Exploratory Analysis." Journal of Financial Economics, 20, 317-346;

Hovey, Martin, Larry Li, and Tony Naughton (2003), "The Relationship between Valuation and Ownership of Listed Firms in China." Corporate Governance 11(2), 112-122;

Labus M. (2006), Osnovi ekonomije, the Publishing Centre of the Belgrade Law School;

Labus, M. (2007). Korporativni sektor u Srbiji: Narodni kapitalizam ili tajkunizacija., the Publishing Centre of the Belgrade Law School;

McConnell, John J., and Henri Servaes (1990), "Additional Evidence on Equity Ownership and Corporate Value." Journal of Financial Economics, 27, 595-612;

Milikić, B. B., Janićijević, N., \&Cerović, B. (2012). Two decades of post-socialism in Serbia: Lessons learned and emerging issues in human resource management. Journal for East European Management Studies, 445-463.

Miljković, M, Filipović, S., Tanasković, S. (2013) „Market concentration in the banking sector: evidence from Serbia”, Industrija br. 2, Vol 41 Ekonomskiinstitut, Beograd. ISSN 0350-0373, UDK 330.322:628.1(497.11). str. 7-27.

Nikolić, I. \& Kovačević, M. (2014), The Impact of Privatization - Empirical Analisys and Results in Serbian Industries, Časopis Industrija, 42(1), 63-86;

Prasnikar, J., Mikerevic, D., \&Voje, D. (2014). Blockholding and organisational diversity: the case of a transition economy. Journal for East European Management Studies, 19(3), 277-304.

Prowse, Stephen D. (1992), "The Structure of Corporate Ownership in Japan." Journal of Finance, Vol. 47(3), 1121-1140;

S. Deakin, R.Hobbs. S. Konzclmann and F. Wilkinson (2001), Partnership. Ownership and Control: The Impact of Corporate Governance on Employment Relations; 
Leković B., Marić S.: The Nature of Corporate Governance and Performance in the...

Shleifer, Andrei, and Robert W. Vishny (1986), "Large Shareholders and Corporate Control." Journal of Political Economy, 94(3), 461-488;

Shleifer, Andrei, and Robert W. Vishny (1997), "A Survey of Corporate Governance." Journal of Finance, 52, 737-783;

Steger, T., \&Hartz, R. (2005). On the way to "good" corporate governance? A critical review of the German debate. Corporate Ownership and Control, 3(1), 9-16. 